\title{
Study on Compound Talents Training Mode of Economics
}

\author{
Xulei Chi \\ School of Finance, Qilu University of Technology, Jinan, P R.China
}

\begin{abstract}
With the rapid development of China's economics, the compound talent is an important mode of personnel training in colleges and universities. Training mode in Colleges and universities has certain significance for training talents, and achieved good effect, but there are some problems, is not conducive to the cultivation of talents. This paper further explains the connotation of economic talents, cultivating model analysis, and think about the problems of economics of compound talents training. Finally, propose the development and solutions combined with the actual.
\end{abstract}

Index Terms - Economics, Compound Talents, Training Mode

\section{The Meaning of Compound Economics Talents}

Compound economics talents, refers to a broad expertise and extensive cultural awareness, with a variety of capabilities and development potential, as well as the harmonious development of personality and creative talent. Economy class talents not only have outstanding experience in economic and professional skills, but also have the relevant skills higher.

Ability characteristics of the compound talent of economic: To have a comprehensive, innovative. The formation of charitable foundation and multidisciplinary knowledge blending to ability, But the simple sum is not the subject ability, but between each other and comprehensive ability based on various ability, its comprehensive function in practice.

\section{Training Mode Status of Compound Economics Talents}

University training model of compound economics talents currently used around the world mainly in the following two ways: One is the general education training mode. This refers to the students have the necessary humanities, social science and natural science knowledge, give the necessary professional knowledge, but their relations on the basis of knowledge and expertise is relatively loose, mainly focused on the basic quality of training, United States, Britain, Japan and other countries universities are basically using this model. The second is the professional education training mode. This refers primarily to give students the basic knowledge needed for professional and settings, basic ability is mainly for professional services. There is a closer relationship between their basic knowledge and basic skills and expertise. The former Soviet Union and our country are very typical mode of specialist education, German, France also tend to this kind of mode.

Training Mode Status of compound economics talents Is different from the ordinary general education training mode, but also from professionals education training mode, It is one kind of personnel training pattern appeared along with the social and economic internationalization development of compound economics talents demand. This training model for the study of the survival and development of the economy class vocational colleges has far-reaching significance.

\section{The Problems of the Mode of Cultivating the Economic Talents}

According to summarize economic colleges training model above the world, there is a problem of our current economy class compound talents training mode.

\section{A. Curriculum scattered isolated, lack of systematic}

The serious problem of curriculum setting in the mode of training talents of many colleges and universities in international trade major as an example, there are two specific performance: First, the curriculum is too friable, many colleges and universities focus on course in economics; Second, the curriculum group from different disciplines fragmented, independent creation of each course, the lack of a unified professional orientation. By different departments to undertake courses in different disciplines, difficult to form the exchange and cooperation between courses, Each course is not so effective in serving the complex system engineering personnel training, Curriculum presented as a mutually blend big "platter."

\section{B. The way of cultivating disjointed, lack of conformity}

In recent years, the effectiveness of personnel training compound unsatisfactory, this theory teaching, experiment and practice and social practice and so on, have a direct relationship between the lack of conformity. University basically is a continuation of the traditional teaching way and method, from book to book, divorced from reality; Limited practical teaching and nowhere near enough away from the society of the first line. The compound talents training cannot combine theory with practice, academic research can not be combined with social experience.

\section{Teachers configuration independently, lack of synergy}

Interdisciplinary and multi-disciplinary complex of professional education, determine its faculty necessarily have different disciplines and professional backgrounds. In international trade major as an example, the teachers are from the management science, economics and finance. Such a special structure of the teachers there are obvious defects: First, the limitations and rely on the professional background, making teachers accustomed to the old concerns and points of interest; Second, there is a large span between the various disciplines, making teaching exchanges and communication between teachers more difficult. Particularity of professional teachers led directly to the fatal defect complex talent teacher training process configuration on ----- independent, lack interoperability. 


\section{Cultivation Mode of Compound Economics Talents}

Comprehensive overview of several compound talent, made a comprehensive training model compound talents vision.

\section{A. Compound talents of economic and legal}

The basic idea of compound talents of economic and legal model is: Lay a solid foundation in the adaptability to broaden professional face of the premise, ability to train professionals in the direction of the flexible, Improve the quality of the overall optimization (knowledge, ability and quality structure and curriculum structure optimization, etc.), Training specialized personnel in both economy, and understand the law of resilience and competitiveness for the society. The main idea through the development of comprehensive training plan, setting the overall optimization of the curriculum system and so on..

\section{B. Compound talents of economic and trading}

With China's accession to the World Trade Organization (WTO), the domestic enterprise internationalization has become an inevitable trend. The number of compound economics talents of domestic is small who is in line with the international economic conditions of the talent. The main reason is that our country economy professional knowledge unitary. This situation not only increases the cost of employing enterprise, but also become a bottleneck for international development. Therefore, developing foreign trade situation of economic talent is required.

\section{Economic management talents}

Finance, accounting, marketing and other professional can learn logistics management, e-commerce, accounting, marketing, managements of public utilities and other aspects of the curriculum, learning and research can be carried out in accordance with the direction of arrangements freely select personal preferences and course. Emphasis on multidisciplinary penetration, training base wide knowledge, with a solid management, economic, legal, financial and other aspects of knowledge, have the basic ability to analyze and solve financial, financial problems, and be able to understand the theory and development of cutting-edge dynamic disciplines.

\section{Conclusion}

Although the compound talents carried out in our country for 20 years, achieved some success, however, there are many theoretical issues that we need to explore solutions, especially on compound talent training mechanism. How there are plans to develop specific areas of compound talents, how to develop reasonable and effective compound talents training programs and so on, We need to increase from psychological research, knowledge structure, thinking to explore other aspects, in order to explore the complex talent training mechanism in line with our reality.

\section{References}

[1] Wuyunzhu, "Research on the model of training compound talents in local colleges and Universities", Education and occupational, July 2009

[2] Genghuaping, "Theoretical and practical significance on compound talents training," Journal of Yangzhou University, December 2003

[3] Liangshuzhu," Employment status of graduates and analysis guidance". Consumer Guide January 2009 